\title{
KONTRUKSI PEMIKIRAN FEMINIS ISLAM INDONESIA DALAM PERSPEKTIF POSTMODERNISME (STUDI PERDA SYARIAH)
}

\author{
Kana Kurniawan \\ Mahasiswa Doktoral Pengkajian Islam, Konsentrasi Syariah (Gender Mainstreaming) \\ SPs UIN Jakarta, Fellowship Nuffic-Lemhannas RI \\ Email: kanakurnial@gmail.com
}

\begin{abstract}
Abstrak
Sejak wacana gender banyak diwacanakan di Indonesia. Para aktivis feminis berperan penting memperjuangkan hak-hak perempuan. Mulai dari mengkritik konsep patriarki hingga HAM yang tidak akomodatif. Seperti yang diungkapkan Saparinah Sadli.1 Kalangan feminis Islam pun mengkaji dogma agama hingga perda "Syariah" yang patriarki pasca UU Otonomi Daerah 32/2004. Regulasi itu dianggap diskriminatif dan patriarki. Perempuan sebagai sub-ordinat laki-laki (Musdah Mulia, 2005).

Penulis menggunakan teori postmodernisme (Gill Branston and Roy Stafford, 2003) untuk menelaah pemikiran feminis Islam terhadap perda-perda itu. Komnas perempuan (2014) mengungkapkan, ada 365 perda diskriminatif terhadap perempuan. Bisa dikatakan, aspirasi kelompok Islamis mendapatkan legal-formal sekaligus dukungan politik atas perda itu. Antara eksekutif dan legislatif saling keterkaitan dengan kalangan formalis syariah.
\end{abstract}

Kata kunci: Postmodernisme, HAM Perempuan, Perda Syariah dan Hukum Islam

\begin{abstract}
Since the gender discourse has been widely discouraged in Indonesia. Feminist activists play an important role in fighting for women's rights. Starting from criticizing the concept of patriarchy to human rights that are not accommodating. As stated by Saparinah Sadli. Islamic feminists also study religious dogma to patriarchal "Sharia" regional regulations after the UU Otonomi Daerah 32/2004. The regulation is considered discriminatory and patriarchal. Women as subordinates of men (Musdah Mulia, 2005).

The author uses postmodernism theory (Gill Branston and Roy Stafford, 2003) to examine Islamic feminist thinking on that regional regulations. The National Commission on Women (2014) revealed that there are 365 discriminatory regulations on women. That said, the aspirations of Islamist group got legal-formal and political support for the regional regulation at once. The executive and the legislative are interrelated with sharia formalists.
\end{abstract}

Keywords: Postmodernism, Women's Human Rights, Sharia Regulations and Islamic Law

${ }^{1}$ Saparinah Sadli, "Hak Asasi Perempuan Juga Hak Asasi Manusi" dalam Berbeda tetapi Setara (Jakarta: Kompas Media Utama, 2010), 244 


\section{A. PENDAHULUAN}

\section{Konteks Kajian}

Pahlawan perempuan Indonesia bisa disebut pembuka kiprah perjuangan feminis. Mereka gigih serta berani menegakkan hak-hak pembebasan bangsa dan hak perempuan secara khusus. Inspirasi perjuangan mencari keadilan itu bisa dilihat dari enam pahlawan perempuan, yaitu: Raden Ajeng Kartini, Cut Nyak Dhien, Cut Nyak Meutia, Raden Dewi Sartika, Martha Christina Tiahahu, Rangkayo Rasuna Said. ${ }^{2}$ Kemerdekaan Indonesia dari penjajahan dan kemajuan pemikirannya secara integral tidak terlepas dari kaum perempuan itu.

Pasca kemerdekaan para pelanjut perjuangan kaum perempuan terus menjadi jangkar nasionalisme dalam ke-Bhineka-an. Revolusi Agustus 1945, perempuan menggalang kekuatan perjuangan melawan penjajah. Mereka mendirikan dapur umum, pos-pos Palang Merah hingga perang fisik bersama laskar-laskar. Solidaritas atas penderitaan yang sama, perempuan mulai masuk dalan kegiatan sosial politik. Kemudian terselenggara Kongres Perempuan pertama pada Desember 1945 di Klaten, Jawa Tengah.

Demi memperkuat basis gerakan, para aktivis perempuan ini membentuk organisasi Persatuan Wanita Indonesia (Perwani) dan Wanita Negara Indonesia, tetapi kemudian berfusi menjadi Persatuan Wanita Republik Indonesia (Perwari). Seperti tidak ingin ketinggalan, di luar Perwari banyak bermunculan organisasi perempuan lain, diantaranya: Badan Kongres Wanita Indonesia (Kowani) tahun 1950; Ikatan Bidan Indonesia (1951); Ikatan Guru Taman Kanak-kanak (1951); dan Perhimpuan Wanita Universitas

\footnotetext{
${ }^{2}$ www.pusakaindonesia.org
}

Indonesia (1957). ${ }^{3}$ Begitu pun di organisasi kemasyarakatan Islam bermunculan. Ada Fatayat NU (1950), Nasyi'atul Aisyiah Muhammadyiah (1931), Wanita Persatuan Ummat Islam (PUI) pada 1952. ${ }^{4}$

Sejak 1965-1970 atau pasca Orde Lama sampai era Orde Baru muncul Serikat Pekerja, dan Himpunan Kerukunan Tani Indonesia (KHTI). Era ini banyak berdiri Lembaga Swadaya Masyarakat (LSM) atau NonGoverment Organization (NGO) yang diprakarsai para aktivis independen. Mereka bekerja menyuarakan isu-isu hak masyarakat. Di dalamnya terkait hak hukum, hak konsumen, hak perempuan serta anak. Banyak lembaga donor dari Amerika dan Eropa tertarik pada program-programnya dan memberikan dana hibah kepada NGO ini sebagai 'watch-dog' dari warga sipil. $^{5}$

Di masa Orde Baru, api perjuangan perempuan tidak begitu signifikan. Soeharto menjadikan gerakan perempuan "mati suri." Mereka yang kritis memilih jalur bawah tanah pergerakannya. Saparinah Sadli mengatakan, bahwa diskursus tentang hak-hak perempuan baru marak dibincangkan tahun 1990. Sebab Deklarasi Universal Hak Asasi Manusia (DUHAM) tahun 1948 belum ditransformasikan terhadap isu-isu gender. Dan tidak secara eksplisit mengakomodasi penuh isu-isu perempuan dalam kehidupannya. Tambahnnya lagi, hak perempuan

3 Sejarah Pergerakan Perempuan Indonesia. http://www.scrib.com. (diakses 17 Juni 2016)

4 Pedoman Dasar dan Pedoman Rumah Tangga Wanita Persatuan Ummat Islam (Wanita PUI), (Jakarta: Wanita PUI, 2011), 12

${ }^{5}$ Siti Ruhaini Dzuhayatin, Rezim Gender Muhammadiyah Kontestasi Gender, Identitas dan Eksistensi (Yogyakarta: Suka Press-Pustaka Pelajar, 2015), 105 
masih bisa dilanggar oleh hukum maupun adat atau tradisi yang ada. ${ }^{6}$

Geliatnya semakin masif pasca Orde Baru tumbang. Berbagai kalangan dari kelompok Islam modern-progresif dan modern-konservatif saling mempengaruhi kebijakan di setiap level. Meski, presiden Abdurrahaman Wahid (Gus Dur) mewakili kelompok modern-kritis (kontekstual) dari kalangan tradisionalis berhasil menggolkan Instruksi Presiden No 9/2000 tentang Pengarusutamaan Gender (PUG) dalam Pembangunan Nasional. Golongan modernkonservatif atau tekstual juga melakukan gerakan masif terhadap pelembagaan hukum Islam di perdaperda. Utamanya posisi perempuan sebagai objek utama regulasi itu.

Regulasi ini yang kemudian disebut perda syariah mendapat kritik tajam dari para feminis Islam dan aktivis HAM. Mereka memandang perda syariah sangat diskriminatif dan bertentangan dengan HAM. Sebagaimana fokus kajian ini mengkaji pemikiran feminis Islam terhadap perda Syariah yang diskriminasi terhadap perempuan dengan menggunakan teori post modernisme.

\section{Pertanyaan Penelitian}

Berdasarkan penjelasan landasan permasalahan diatas, maka diajukan pertanyaan kajian ini yaitu: bagaimanakah konsep pemikiran feminisme Islam perspektif Postmodernisme terhadap perda "Syariah" bias gender di Indonesia? Dan apa bisa teori - teori Postmoderenisme bisa mempengaruhi pemikiran feminis muslim dalam menegakkan hak-hak perempuan?

\section{Tesis Statement}

${ }^{6}$ Saparinah Sadli, "Hak Asasi Perempuan Juga Hak Asasi Manusi," dalam Berbeda tetapi Setara, (Jakarta: Kompas Media Nusantara, 2010), 248 \begin{tabular}{llr} 
Kajian ini & bertujuan untuk \\
membuktikan & bahwa & teori \\
postmodernisme & \multicolumn{2}{c}{ mempengaruhi } \\
pemikiran feminis & muslim Indonesia \\
terhadap perda & "Syariah" yang
\end{tabular} diskriminatif perempuan. Tumbuh kembangnya perda-perda serupa mendapat kesempatan terbuka setelah Aceh Menerapkan Syariat Islam dan berlakunya UU Otonomi Daerah tahun 2004.

\section{B. LANDASAN TEORI}

Kelahirannya postmodernisme merupakan antitesis modernisme. Ia merefleksikan kelahirannya secara kritis terhadap paradigma modernisme. Kemunculannya ditandai dengan kebangkitan religiusitas keagamaan. Konsep-konsep modernisme yang mengkiblatkan diri terhadap barat dianggap bersekongkol dengan kapitalisme (global).

Awal permulaan Postmodernisme menurut Shofwan Rozi digaungkan John Watkins Chapman di tahun 1870an. Kemudian muncul kembali di tahun 1917 yang didengungkan Rudolf Panwitz tetapi berbeda dengan term Post Impresionisme (1880-an) maupun post industrial yang bertahan selama delapan tahunan (1914-1922). Adapun pemikiran yang diwarnainya, terutama di tahun 1960-an adalah pemikiran sosial, ilmu ekonomi dan agama yang secara khusus disebut post Christianity. $^{7}$

Hal yang mendasar perbedaan antara postmodernisme dan postmodernitas menurut I Bambang Sugiharto. Pembedaan ini sesuai dengan kritikan Turner dan Ernest Gellner. Bahwa postmodernisme

\footnotetext{
Shafwan Razi, "Agama dan Postmodernisme: Menelusuri Metodologi dan Pendekatan Studi-Studi Agama" dalam Ilmu Ushuluddin, Volume 1, Nomor 3, Januari 2012. Bisa dilacaka dalam Richard Appignanesi dan Chris Garratt, Mengenal Postmodernisme for Beginners (Bandung: Mizan, 1998), 23
} 
merupakan gambaran dunia (world view), epistemologi maupun ideologiideologi modern. Berbeda dengan postmodernitas yang didefinisakan dalam kerangka era global, menghargai heterogenitas, dan keberaragaman yang menstimulan dalam menafsir ulang wacana yang sudah berjalan. Lalu mewabahnya determinasi, inderteminasi, ${ }^{8}$ dan konsumerisme. Shofwan Rozi memotret lain diantaranya terjadi deregulasi pasar uang maupun fasilitas publik, hingga negara bangsa dicap tidak berdaya. ${ }^{9}$

Sisi kemajuan dari kelahiran postmodernisme membawa kepada citacita yang berkeadilan. Hidup yang mencerminkan plural, tumbuhnya iklim demokratis, egaliter, serta terjaminnya hak beragam ideologi. ${ }^{10}$ Inilah alasan kenapa postmodernisme tumbuh kembang sebagai harapan baru. Hidup terjamin dalam HAM global dan diberikan kebebasan menentukan arah, termasuk aspek ekonomi, politik, budaya maupun hukum. Dan tentunya tanpa bayang-bayang kapitalisme.

Sebut saja Harvey Cox. Ia pemikir pertama yang mendasari postmodernisme digunakan dalam studi agama. Begitupun masyarakat yang beragama merespon positif terhadap munculnya. $^{11}$ Maka, bisa dilihat terjadinya wacana keagamaan pasca modern dan gerakan pembebasan berlandaskan visi teologis. David Ray Grifft melihat postmodernisme

${ }^{8}$ Renny Chandradewi, "Modernisme dan Postmodernisme Review Tulisan David Harvey" dalam Journal Issue: Vol. 1/No. 04/27 March 2014

${ }^{9}$ Scott Lash, Sosiologi Postmodernisme, (Yogyakarta: Pustaka Filasafat Kanisius, 2008), 12

10 Shafwan Razi, "Agama dan Postmodernisme: Menelusuri Metodologi dan Pendekatan Studi-Studi Agama" dalam Ilmu Ushuluddin, Volume 1, Nomor 3, Januari 2012

${ }^{11}$ Harvey Cox, Religion and the Secular City: Toward a Postmodernism Theology (New York: Simon and Schuster, 1984), 13 membawa visi spiritual konstruktif atau pembaharuan.$^{12}$

Agar landasan kajian ini terfokus, maka digunakan pendekatan post modernisme yang diungkapkan David Morley. Dalam hal ini, David membagi 4 hal yaitu: 1. Jangka waktu kehidupan social, 2. Sebuah bentuk cultural sensibility, 3. Sebuah bentuk estetika 4 . Sebuah pemikiran dalam mengkaji jarak waktu. Nomer terakhir ini bisa kemunculannya bisa melebihi teori post-strukturalis. ${ }^{13}$ Kemudian 3 hal dikontruksi sebagai berikut: ${ }^{14}$ pertama, A Period of social life - postmodernity? Kata "post" didefiniskan sebagai waktu atau masa yang sudah terjadi. Dengan tambahan "modern" atau "modernitas" merupakan masa awal kemajuan indrustri (Indrustrial Evolution) di Eropa; kedua, A Form of Cultural Sensibility Charasteristic of this Period.? Melalui struktur postmodernisme Marxis mengalami perubahan sosial-ekonomis yang menghasilkan suatu "cultural logic" atau "structure feeling" yang merubah rasa sensitivitas manusia akan suatu realitas; dan ketiga, An aesthetic style?. Aspek ketiga erat kaitannya dengan media computer yaitu: ${ }^{15}$ Hibridity, The Bluring of real and simulated, The Erasion of history (penghilangan sejarah), Intextual reference, Disjointed narrative structure yang disebut ciri ketidak pastian atas teori

\footnotetext{
12 David Ray Grifft, Tuhan dan Agama dalam Dunia Postmodernisme (Yogyakarta: Pustaka Filsafat Kanisius, 2005), 17

13 Gill Branston and Roy Stafford, The Media Student's Book, Third Edition, (London and New York: Routledge, 2003), 387-389.

14 Gill Branston and Roy Stafford, The Media Student's Book, Third Edition, (London and New York: Routledge, 2003), 387-389.

15 Gill Branston and Roy Stafford, The Media Student's Book, Third Edition, (London and New York: Routledge, 2003),387-340.
} 
postmodernisme (relative dari postmodernisme). ${ }^{16}$

\section{PEMBAHASAN}

Sumber utama hukum Islam adalah al-Qur'an dan hadits. Segala permasalahan ditafsirkan dengan dua sumber hukum tersebut. Baik ibadah ritual hingga kehidupan dalam berbangsa dan bernegara. Namun demikian, otoritas penafsirnya memiliki legitimasi yang sesuai dengan ijma' para shahabat, $t a>b i{ }^{\prime} i>n-t a>b i{ }^{\prime} a>t$ dan 'ulama $>$. Fatwa tiga kelompok ini menjadi hukum setelah al-Qur'an dan hadits. ${ }^{17}$ Oleh sebabnya, tidak semua umat Islam boleh dan mampu menafsirkan. Butuh ilmu yang komprehensif.

Hukum Islam sebuah istilah lain dari syari'at adalah pokok-pokok ajaran dari tafsiran yang telah disepakati. ${ }^{18}$ Sebuah tatanan regulasi yang dikenalkan Rasulullah SAW dalam mengelola kehidupan di Mekah. Hukum baru sebagai antitesis adat istiadat masyarakat jahiliah Quraisy. Seperti dikenal sebelumnya, budaya suku Quraisy bertolak belakang dengan hak-hak masyarakat (termasuk hak-hak perempuan) atau istilah sekarang disebut HAM. Perempuan sangat dimuliakan dan terhormat, setara dengan laki-laki. Berbeda di masa pra

16 Gill Branston and Roy Stafford, The Media Student's Book, Third Edition, (London and New York: Routledge, 2003), 340

17 Muhammad ibn Ahmad ibn 'Abd al$\mathrm{Ha}>\mathrm{di}>$ al-Dimashqi> (744), Thabaqa $>t$ 'Ulama> al-Hadith (Beirut: Muassasah al-Risa>lah, 1996), C. II, tahqi>q: Akram al-Bu>shi dan Ibra $>$ hi $>\mathrm{m}$ alZaybaq), Juz II, hlm. 389 - 401.

18 Merujuk kepada pandangan Ismail Yusanto juru bicara HTI, syariat (al-syari>at) bermakna sumber air minum (mawrid al ma> 'li li al istisqa>) atau jalan lurus (at-thari>q almustaqi $>m$ ). Jelasnya, semua hukum yang diambil dari sumber-sumber hukum Islam merupakan syari>at Islam (al-ahkam asy-syar'iyyah). Ismail Yusanto, "Selamatkan Indonesia dengan Syariat" dalam Burhanudin (ed.)Syariat Islam Pandangan Muslim Liberal (Jakarta: JIL dan TAF, 2003) 145
Islam. Bayi perempuan dibunuh sebab dianggap membawa petaka. ${ }^{19}$ Fatimah Mernisi sependapat, era Islam awal perempuan merasakan kemerdekaan. ${ }^{20}$

Dalam istilah modern, kajian tentang perempuan dikenalkan dengan istilah gender. Perempuan dengan hak dan kewajibannya sejajar dengan lakilaki (keadilan gender). Zaitunnah Subhan dengan meminjam istilah Jhon M. Echols, gender adalah jenis kelamin. Nasaruddin Ummar menambahkan, istilah gender bukan hanya jenis kelamin. Tapi sosio-kultural masyarakat yang merubahnya. Atas dorongan itu terjadi perbedaan perilaku, mentalitas serta emosional kedua pihak. ${ }^{21}$ Menguatkan pendapat John, ia mengidentifikasi dari potret sosial budaya antara laki-laki dan perempuan. $^{22}$ Selanjutnya perempuan disebut sebagai kaum feminim dan pemahamannya adalah feminisme. $^{23}$

Kemunculan gender sangat dipengaruhi oleh tempat, zaman/waktu, suku/ras/bangsa, budaya, pemahaman agama, ideologi negara, politik, hukum serta ekonomi. ${ }^{24}$ Berdasarkan hasil kajian Margot Badran, ada dua bentuk gerakan feminisme di Timur Tengah,

19 Musthafa al-Siba>'i, al-Mar'ah baina al-Fiqh wa al-Qa>nu>n (Damaskus, Halb: alMaktabah al-'Arabiyat), 37

${ }^{20}$ Fatimah Mernisi, Beyond the Veil MaleFemale Dinamics in Modern Muslim Society (Indiana: Indiana University Press, 1987), xii-xiii

${ }^{21} 42$

22 Zaitunah Subhan, Al-Qur'an dan Perempuan, (Jakarta: Kencana, 2015), 1. Lihat Nasaruddin Umar, Perspektif Jender Dalam AlQur'an, (Disertasi, IAIN Syarif Hidayatullah Jakarta, 1999), 42

23 Sebagaimana Irsyadunnas merujuk pemikiran David Jary and Julia Jary, Collins Dictionary of Sociology (Glasgow: Harper Collins Publisher, 1991), 223-224. Lihat Irsyadunnas, Hermeneutika Feminisme dalam Pemikiran Tokoh Islam Kontemporer (Yogyakarta: Kaukaba, 2013), 39

24 Zaitunah Subhan, Al-Qur'an dan Perempuan Menuju Kesetaraan Gender dalam Penafsiran (Jakarta: Prenada Media Group, 2015), 3 
yaitu feminisme sekuler (awal abad 20) dan feminisme Islam. $^{25}$ Sesuai namanya, feminisme sekuler melandasi konsep ajarannya dengan kebebasan serta terbangunnya kesetaraan laki-laki dan perempuan.

Berbeda dengan feminisme Islam, yang mengafirmasi prinsip-prinsip kesetaraan dengan ajaran-ajaran yang bersumber dari al-Qur'an. ${ }^{26}$ Poin mendasarnya adalah bahwa ajaran Islam yang berkeadilan memfasilitasi hubungan antarmanusia (laki-laki dan perempuan). Di samping itu, feminis Islam menegaskan prinsip-prinsip Islam atas dasar kesetaraan, persaudaraan serta kemaslahatan. ${ }^{27}$

Bedahalnya konservatisme dalam menafsirkan al-Qur'an yang secara tidak langsung membangun sosiobudaya patriarki. Penafsiran dengan segala argumennya dibangun dari beberapa hal: subordinasi perempuan berdasarkan teks Q.S al-Nisa>: $34 .^{28}$ Husein Muhammad memahami terjadinya pemahaman, bahwa perempuan subordinasi laki-laki dan

${ }^{25}$ Margot Badran, "Understanding Islam, Islamism and Feminism" dalam Women and Islam: Critical in Sociology, ed. Haidah Moghissi (New York: Routledge, 2005), 258-263

${ }^{26}$ Margot Badran, "Understanding Islam, Islamism and Feminism" dalam Women and Islam: Critical in Sociology, ed. Haidah Moghissi (New York: Routledge, 2005), 258-247

27 Siti Musdah Mulia (ed.) Keadilan dan Kesetaraan Gender Perspektif Islam (Jakarta: Lembaga Kajian Agama dan Jender, 2003), 75

28 "Laki-laki itu adalah (qawwamun) pemimpin bagi kaum wanita, oleh karena Allah telah melebihkan sebahagian mereka (laki-laki) atas sebahagian yang lain (wanita), dan karena mereka (laki-laki) telah menafkahkan sebagian dari harta mereka. Sebab itu, maka wanita yang saleh, ialah yang taat kepada Allah lagi memelihara diri ketika suaminya tidak ada, oleh karena Allah telah memelihara (mereka). Wanitawanita yang kamu khawatirkan nusyuznya. Maka nasehatilah mereka dan pisahkanlah mereka di tempat tidur mereka, dan pukullah mereka. kemudian jika mereka mentaatimu, Maka janganlah kamu mencari-cari jalan untuk menyusahkannya. Sesungguhnya Allah Maha Tinggi lagi Maha besar." laki-laki-laki sebagai makhluk superioritas didasarkan tafsiran para ulama klasik seperti Abu Ja'far Muhammad bin Jarir Al-Thabari, Abdullah Muhammad al-Qurthubi dan Imad al-Din Ibnu Katsir. Berbeda dengan Rasyid Ridha, ia mengatakan bahwa kepemimpinan sebagai perkara adat kebiasaan (al-umur al-'urfiyah) untuk kemaslahatan. ${ }^{29}$

Kyai Feminis, Husein Muhammad mengatakan kearifan al-Qur'an dalam memposisikan laki-laki dan perempuan dilihat dari diturunkannya al-Qur'an yang bertransformasi secara kultural. Nilai kesetaraan yang dibangun alQur'an tidak dilimpahkan secara konfrontatif serta frontal. Karenanya, sambutan atas ajaran Islam yang memberikan perlindungan dan menjaga martabat perempuan bisa mereformasi sturktur sosial-budaya masyarakat. ${ }^{30}$

Faqihuddin Abdul Qodir menggambarkan prinsip keadilan yang setara dituangkan dalam Sholawat Keadilan. Bait keempat yang ia tulis sangat menjiwai tentang bagaimana keadilan bagi perempuan. Kehidupan antara laki-laki dan perempuan serta semua manusia yang tidak berkeadilan akan tidak bisa merasakan keadilan, "sesungguhnya, kita tidak akan pernah biasa merasakan keadilan dalam hidup, jika tanpa keadilan untuk kita semua, laki-laki dan perempuan. ${ }^{31}$

\section{a. Transformasi Ajaran Feminisme}

Berdasarkan penelusuran Budhi Munawar Rahman, lahirnya pemikiran gender ke Indonesia, disebabkan tiga hal: pertama, adanya transformasi pemikiran feminisime Barat ke dalam

\footnotetext{
${ }^{29}$ Husein Muhammad, Islam Agama Ramah Perempuan (Yogyakarta: LKiS, 2004), 8183

30 Husein Muhammad, Islam Agama Ramah Perempuan (Yogyakarta: LKiS, 2004), 17

31 Faqidudin Abdul Kodir, Shalawat Keadilan Relasi Laki-laki dan Perempuan dalam Teladan Nabi, (Cirebon: Fahmina Institute, 2003) 21
} 
masyarakat Indonesia. Kedua,
terbukanya jabatan publik bagi perempuan yang tentunya membawa paradigma baru tentang egalitarianisme sesuai kemampuan, serta banyaknya penyerapan lapangan pekerjaan bagi perempuan. Ketiga, semakin menguatnya ekspresi politisi perempuan secara umum di negaranegara Islam dan tanpa terkecuali Indonesia. $^{32}$

Jika melihat faktor-faktor yang mempengaruhi pemaknaan gender, semisal dari sisi pemahaman agama dan ideologi, politik serta hukum. Kalangan islamis dalam merespon gender sebagai pemahaman "Barat" yang bertentangan. Dengan pemikiran patriarkal, perempuan (seharusnya) diatur dalam regulasi "Syariah." Dalam pembacaannya, formalisasi syari'ah (termasuk mengatur perempuan) bukan hal baru, tetapi sejak jaman penjajahan Belanda sudah masuk prinsip-prinsip ajaran agama Islam dalam konstitusi negara. ${ }^{33}$

${ }^{32}$ Budhy Munawar Rahman mengatakan perkembangan feminisme bisa ditelusuri dari abad XX. Di abad ini lahir para pemikir feminis, yaitu 'Aisyah Taymuniyah, Zainab Fawwaz, Rokeye Sakhwat Hosein, Nazzar Sajjad Haydar, Emilie Ruete, Taj al-Salthanah, Huda Sya'rawi, Malak Hifni Nasir, Nabawiyah Musa, Fetme Aliye dan RA. Kartini. Budhi Munawar Rahman, "Islam dan Feminisme: dari Sentralisme kepada Kesetaraan," dalam Membincang Feminisme Diskursus Gender Perspektif Islam, ed. Mansur Faqih (Surabaya: Risalah Gusti, 1995), 201. Zaitunah Subhan, AlQur'an dan Perempuan Menuju Kesetaraan Gender dalam Penafsiran (Jakarta: Prenada Media Group, 2015), 12

33 Sejak Indonesia dalam penjajahan Pemerintahan Hindia Belanda, sumber hukum Indonesia (nusantara) mengalami dinamika yang kompleks. Tarik-menarik kepentingan politik menjadikan regulasi tidak berdiri sendiri. Ada faktor sosial-politik, budaya, agama serta pertahanan dan keamanan. Ujian kedaulatan hukum telah dialami sejak Pemerintah Hindia Belanda mengeluarkan politik hukumnya melalui Undangundang Hindia Belanda Reglement op het beleid der Regeering van Nederlandsch Indie atau Regeerings Reglement (R.R.) dalam Stbl. 18552: 2. Lalu kedatangan VOC mengeluarkan legislasi
Begitu pula di era Orde Baru melalui konstitusi negara, regulasi yang terkait dengan perempuan yang bersumber dari hukum Islam. Melalui Ketetapan MPRS No. II/MPRS/1960 disebutkan bahwa kesempurnaan hukum perkawinan maupun waris harus memasukan unsur agama hingga regulasi itu tidak berlaku lagi. Politik akomodasi dalam perundangan bisa dilihat dalam UU No.1/1974 tentang Perkawinan (lihat pasal 2 dan 63). ${ }^{34}$ Dasar kekuatan lain dalam keadilan dan penghormatan terhadap HAM ada pada preambule UUD 1945 yang mengandung aspek politis, religius serta moral yang menolak bentuk diskriminasi terhadap ras, agama dan kepercayaan. ${ }^{35}$

Berdasarkan preambule UUD 1945 itu, demikian jelas bahwa hukum harus menjunjung rasa keadilan. Perempuan

Resolutie der Indische Regeering di 25 Mei 1760. Tidak hanya itu, pemberlakuan hukum Islam sejak VOC dikuat Pemerintah Hindia Belanda dengan Regeeringsreglement tahun 1855 pasal 75 ayat 3 R.R.Hukum Islam itu meliputi hukum perkawinan dan waris. Pasal 75 ayat 3, "Oleh hakim Indonesia itu hendaklah diperlakukan Undang-undang agama (godsdientige wetten) dan kebiasaan penduduk Indonesia itu; ayat 4, "Undang-undang agama, instellingen dan kebiasaan itu jugalah yang dipakai untuk mereka oleh hakim Eropa pada pengadilan yang lebih tinggi andai kata terjadi hoger beroep atau permintaan pemeriksaan banding." Ismail Suny, 51-52. Namun demikian, menurut Ismail Suny, atas desakan Snouck Hurgronje dan protes Cornellis Hugronje, hukum Islam dicabut dari tata hukum Hindia Belanda yang diganti dengan Wet op de staatsinrichting van Nederla nds - indie (Indische Staatsregeling) pasal 134 ayat (2). Dalam hal terjadi perkara perdata antara sesama orang Islam, akan diselesaikan oleh hakim agama Islam apabila hukum adat mereka menghendakinya dan sejauh tidak ditentukan lain dengan sesuatu ordonansi"

${ }^{34}$ Pasal 2, "Perkawinan adalah sah apabila dilakukan menurut hukum masing-masing agamanya," dan dalam Pasal 63, yang dimaksud pengadilan adalah pengadilan agama bagi yang beragama Islam.

35 Ismail Suny, "Hukum Islam dalam Hukum Nasional" dalam Jejak-jejak Hukum Islam dalam Sistem Ketatanegaraan Indonesia (Jakarta: Konpress, 2005), 58-59 
disejajarkan sebagai masyarakat yang setara. Tidak ada regulasi diskriminatif atas nama kekuasaan. Tetapi hasil kajian Savitri dengan menggunakan teori hukum feminis, bahwa hukum (KUHP) Indonesia diskriminatif dan tidak adil terhadap perempuan. ${ }^{36}$ Alasannya adalah sebagaimana dipaparkan Margaret Davies, hukum Indonesia secara empiris patriarki. Artinya hukum domain laki-laki, dan terlebih patriarkhi hukum beririsan dengan adat tradisional. ${ }^{37}$

\section{b. Pergumulan Wacana: HAM dan Perda "Syari'ah" Otonomi Daerah}

Terkait tujuan hukum Islam Masdar Farid Mas'udi mengulas kembali al-kulliyyat al-maqa>shid alkhomsah. Hak-hak insani nama lain dari HAM sebagai hak-hak universal, yaitu: hifz an-nafs (perlindungan jiwa dan tubuh); hifz al-'aql (perlindungan akal); hifz $a d-d i>n$ (perlindungan agama/keyakinan); hifz al-ma $>l$ (perlindungan harta benda); dan hifz alirdl wa al-nasl (perlindungan atas kehormatan dan keturunan). Merujuk kepada teori hukum Islam, lima hak universal ini dikelompokkan menjadi tiga, yaitu hak-hak dlarury (primer) yang apabila tidak dipenuhi akan mengakibatkan kematian; hak sekunder (hajiy), jika hak ini tidak terpenuhi akan menimbulkan kesengsaraan (masyaqqat/haraj); dan hak-hak tersier (tahsiny/takmily) apabila tidak dipenuhi mendatangkan ketidaksempurnaan. ${ }^{38}$

${ }^{36}$ Niken Savitri, HAM Perempuan Kritik Teori Hukum Feminis Terhadap KUHP (Bandung: Refika Aditama, 2008), 16

37 Margaret Davies, Asking the Law Question (The Law Book Company Ltd, 1994), 164

${ }^{38}$ UU HAM BAB XA Pasal 28A "Setiap orang berhak untuk hidup serta berhak mempertahankan hidup dan kehidupannya." Pasal 28B (1) "Setiap orang berhak membentuk keluarga dan melanjutkan keturunan melalui perkawinan yang sah." (2) "Setiap anak berhak atas kelangsungan hidup, tumbuh dan berkembang serta
Sebagai langkah maju menghapus diskriminasi dan menegakkan hak perempuan. Orde Baru melalui pengesahan UU No. 7 tahun 1984 tentang Pengesahan Konvensi Mengenai Penghapusan Segala Bentuk Diskriminasi Terhadap Wanita (Convention on the Elimination of All Forms of Discrimination againts Women). Karenanya, semua perundangan harus berorientasi kepada keadilan bagi perempuan termasuk perangkat lainnya. Bagi sejumlah kalangan, regulasi ini menjadi awal perubahan penghormatan hak-hak perempuan. Namun masih banyak ditemukan pasal-pasal dalam perda syariah yang bertentangan dengan maqa $>$ shid syari> 'ah dan HAM.

Tahun 2004 menjadi awal baru pranata hukum daerah. Daerah memiliki kekuasaan luas menata diri daerahnya, termasuk di dalamnya hukum/peraturan daerah. Hukum daerah sangat progresif dengan desentralisasi sebagai implikasi dari otonomi daerah. ${ }^{39}$ Demokrasi lokal lebih bergairah sebagaimana tuntutan penataan tata tertib warganya. Ni'matul

berhak atas perlindungan dari kekerasan dan diskriminasi." Pasal 28C (1) setiap orang berhak mengembangkan diri melalui pemenuhan kebutuhan dasarnya, berhak mendapat pendidikan dan memperoleh manfaat dari ilmu pasal pasal 28J (1) "Setiap orang wajib menghormati hak asasi manusia orang lain dalam tertib kehidupan bermasyarakat, berbangsa dan bernegara." (2) "Dalam menjalankan hak dan kebebasannya, setiap orang wajib tunduk kepada pembatasan yang ditetapkan dengan undang-undang dengan maksud semata-mata untuk menjamin pengakuan serta penghormatan atas hak dan kebebasan orang lain dan untuk memenuhi tuntutan yang adil sesuai dengan pertimbangan moral, nilai-nilai agama, keamanan dan ketertiban umum dalam suatu masyarakat demokratis." Masdar Farid Mas'udi, Syarah Konstitusi UUD 1945 Dalam Perpekstif Islam (Jakarta: Alvabet, 2011),141-142

${ }^{39}$ Desentralisasi adalah pemerintah pusat memberikan kewenangan yang dibuktikan dengan pengakuan kepada pemerintah daerah terkait dengan pengelolaan potensi maupun kemampuan yang melibatkan legislatif . 
Huda memberikan definisi, bahwa desentralisasi merupakan bentuk pemerintahan lokal (local governance). Sebagaimana uangkapan yang dipinjam dari Harry Friedman, "...a" superior governance - one encompassing a large jurisdiction - aasigns responsibility, authority, or function to 'lower' government unit - one encompassing a smaller jurisdiction that is assumed to have some degree of authonomy. " 40

Menurut prinsipnya, otonomi daerah berdasarkan UU No. 22 tahun 1999, mengandung beberapa prinsip: otonomi daerah harus memperhatikan demokrasi, keadilan, pemerataan dan potensi serta keanekaragaman daerah; implementasi luas, berdasarkan kenyataan serta dapat dipertanggung jawabkan; otonomi luas dan utuh diberikan kepada pemerintah kabupaten/kota. Sementara kewenangan propinsi terbatas, pelaksanaannya harus mengacu kepada konstitusi negara yang selaras pusat-daerah, memberikan kemandirian, meningkatkan peran maupun fungsi legislatif, asas dekontrasi diberikan kepada pemerintahan propinsi dan asas tugas pembantuan diterapkan secara hirearki, yaitu dari pemerintah kepada desa atau pemerintah kepada daerah dengan cara melaporkan implementasi yang bertanggungjawab. $^{41}$ Kewenangan lain $^{2}$ yang sangat krusial dan strategis, amanah UU No. 32 tahun 2004 memberikan kewenangan yang

${ }^{40}$ Ni'matul Huda, Hukum Pemerintahan Daerah (Bandung: Nusa Media, 2012), cet-III, 61. Lihat juga Harry Friedman, "Decentralized Development in Asia," dalam G. Shabbir Cheema dan Denndi A. Rondinelli (Editors), Decentralization and Development Policy Implementationa in Developing Countries (Beverly Hills/ London/ New Dehli, Sage Publication: 1983), 35

${ }^{41} \mathrm{Ni}$ 'matul Huda, Hukum Pemerintahan Daerah (Bandung: Nusa Media, 2006) 2012), cetIII, 207 mengharuskan pemerintah daerah merancang sebuah legislasi. ${ }^{42}$

Daerah-daerah seperti menemukan titik temu "perubahan." Sejumlah aturan yang bersumber dari agama mayoritas (Islam disebut perda syari'ah), dan (Kristen, perda “injil”) disahkan. Dua agama ini juga paling agresif dalam memasukan ajaran teologinya ke dalam regulasi daerah.

Dalam kajian hukum Islam Indonesia, kewenangan membuat regulasi syari>'ah, membuka kembali perdebatan antara golongan tekstual dan kontekstual. Golongan pro syari>'ah Islam mendorong terbitnya perda syari> 'ah. Memang banyak ditemukan, perda itu terbit seperti halnya hubungan agama dan negara yang tidak terpisahkan, saling membutukan dan melengkapi. ${ }^{43}$

Kelompok tekstual yang gencar mendorong perda shari>'ah diantaranya: Majelis Mujahidin Indonesia (MMI), Hizbut Tahrir Indonesia (HTI), Komiter Persiapan Penegakkan Syari'at Islam (KPPSI)/ Komite Penegakkan Syari'at Islam (KPSI) provinsi Sulawesi Selatan, Gerakan Syari'at Islam provinsi Jawa Barat dan Nanggroe Aceh Darussalam (NAD) ${ }^{44}$

Sebagaimana diungkapkan Arskal Salim dan Azyumardi Azra, ada lima tahapan proses transformasi hukum Islam dalam perundangan, yaitu; pertama, syari>'at Islam diberlakukan untuk hukum keluarga seperti perkawinan, perceraian dan warisan; kedua, syari> 'at Islam untuk ekonomi

\footnotetext{
${ }^{42} \mathrm{Ni}$ 'matul Huda, Hukum Pemerintahan Daerah (Bandung: Nusa Media, 2006) 2012), cetIII, 232

43 Syukron Kami, Pemikiran Islam Tematik Agama dan Negara, Demokrasi, Civil Society, Syariah dan HAM, Fundamentalisme dan Anti Korupsi (Jakarta: Kencana Prenada Media Group, 2013), 3

${ }^{44}$ Haedar Nashir, Gerakan Islam Syariah (Jakarta: Maarif Institute, 2006), 60-62 vol. 1 No. 02 Novemer 2006
} 
serta keuangan, seperti perbankan Islam, maupun zakat; ketiga, syari> 'at Islam untuk ritual keagamaan, seperti larangan alkohol, judi dan kewajiban memakai jilbab bagi perempuan; keempat, syari> 'at Islam diberlakukan untuk pidana Islam serta sanksinya; dan kelima, Islam dijadikan sebagai dasar negara serta sistem dalam pemerintahan. $^{45}$

Proses transformasi ini adalah fakta di tengah arus ketidakpercayaan sebagian masyarakat terhadap keadilan hukum positif negara. Negara sekuler dinilai tidak bisa menjamin rasa keadilan sebagaimana HAM dengan kontruksi demokrasi serta civil soceity sebagai sandarannya. ${ }^{46}$ Maka tidak heran jika gerakan civil society ikut berperan dalam transformasi ini yang dipetakan ke dalam tiga konsep: sebagai budaya (adab masyarakat), merupakan aspek politik beroposisi dengan negara; dan menyatukan antara kedua konsep itu. Lanjutnya lagi, berdasarkan pengamatan Syukron Kamil, demokrasi terbuka membuat kelompok pro syari>'ah bisa disebut yang menerapkan civil society sebagai aspek politik, terus mendorong dikembalikannya Piagam Jakarta kepada konstitusi dan memandang arus negatif globalisasi harus dilawan dengan syari> 'at. Keberhasilan mereka bisa dilihat dari lima puluh kabupaten/kota mengeluarkan perda syari $>$ ' $a$ h. $^{47}$

Mengutip Yenni Zanuba Wahid, persoalan yang mengemuka akibat

\footnotetext{
${ }^{45}$ Arskal Salim and Azyumardi Azra (eds), Sharia and Politics in Modern Indonesia, (Singapore: ISEAS, 2003)

46 Syukron Kamil, Pemikiran Islam Tematik Agama dan Negara, Demokrasi, Civil Society, Syariah dan HAM, Fundamentalisme dan Anti Korupsi (Jakarta: Kencana Prenada Media Group, 2013), 79-80

${ }^{47}$ Syukron Kamil (ed.), Syariah dan HAM Dampak Perda Syariah terhadap Kebebasan Sipil, Hak-hak Perempuan, dan Non-Muslim (Jakarta: CSRC UIN Jakarta dan KAS Jakarta, 2007), xxii
}

peraturan ini banyak melanggar hakhak sipil, perempuan dan non-muslim. ${ }^{48}$ Dan tidak bisa dinafikan kritik tajam banyak diungkapkan kelompok pro demokrasi. Mereka menginginkan adanya hukum yang adil. Tidak menjadikan semua elemen masyarakat sebagai objek, tetapi subjek. Subjek dalam pelibatan secara aktif. Sebagaimana dituliskan dalam Deklarasi Universal hak Asasi Manusi (DUHAM) tahun 1948 oleh PBB, semua orang terjamin hak-hak asasinya serta kebebasannya. ${ }^{49}$ Tidak memandang apakah laki-laki atau perempuan. Mereka mempunyai hak dan kewajiban yang sama. Daniel S. Lev memperingatkan tentang pemerintah konstitusionalis terlahir dari distribusi kekuasaan politik dan sosial yang menjamin adanya hak-hak politik serta keadilan sosial maupun ekonomi. $^{50}$ Menurut Azyumardi Azra penerapan syari>ah Islam di Aceh adalah potret politik darurat (political expediency) agar Aceh tidak lepas dari Indonesia sebagai Negara Kesatuan Republik Indonesia (NKRI). ${ }^{51}$

Hak perempuan mendapat perhatian serius dari dunia hukum internasional. Langkah-langkah antisipatif banyak dilakukan dengan penguatan sejumlah regulasi, sebagaimana diungkapkan Musdah Mulia, diantaranya adalah Konvensi tentang Pengupahan yang Sama bagi Perempuan dan Laki-laki untuk

${ }^{48}$ Syukron Kamil ed., Syariah dan HAM Dampak Perda Syariah terhadap Kebebasan Sipil, Hak-hak Perempuan, dan Non-Muslim (Jakarta: CSRC UIN Jakarta dan KAS Jakarta, 2007), xxxv

49 Musdah Mulia, Muslimah Reformis Perempuan Pembaru Keagamaan (Bandung: Mizan, 2005)

50 Daniel S. Lev, Hukum dan Politik di Indonesia (Jakarta: LP3ES, 2013), cet. ke-3, 501

${ }^{51}$ Azyumardi Azra,"Syariat Islam dalam Bingkai Nation State," dalam Komaruddin Hidayat dan Ahmad Gaus (Ed.), Islam, Negara dan Civil Soceity, Gerakan dan Pemikiran Kontemporer (Jakarta: Paramadina, 2005), 35 
Pekerjaan yang sama Nilainya (1951), Konvensi tentang Hak Politik Perempuan (1953), Konvensi tentang Kewarganegaraan Perempuan yang Menikah (1957), Konvensi Anti Diskriminasi dalam Pendidikan (1960), Konvensi tentang Persetujuan Perkawinan, Umur Minimum bagi Perkawinan dan Pencatatan Perkawinan (1962), dan Konvensi Penghapusan Segala Bentuk Diskriminasi terhadap Perempuan (1979). ${ }^{52}$

Dalam perda syari>'ah terjadi perdebatan tentang posisi perempuan. Adanya perda prostitusi atau jam malam misalnya lagi, perempuan diasumsikan sebagai awal munculnya kejahatan, tidak untuk laki-laki. Inilah yang kemudian disebut bias gender dalam perda syari>'ah. Padahal seharusnya hukum harus bersandar kepada Pancasila dan UUD 1945 yang mengandung prinsip keadilan di hadapan hukum.

Menurut Zaitunah Subhan dengan meminjam istilah Hillary M. Lips, secara terminologi, gender merupakan pembedaan peran, fungsi, emosional, maupun karakteristik maupun perilaku antara laki-laki dan perempuan secara kultural. ${ }^{53}$ Dalam konstitusi negara Indonesia, kemuliaan hak-hak seseorang sudah terjamin sebagaimana dalam UUD 1945 pasal 28I (2) Undang-Undang Dasar Tahun 1945 disebutkan, "Setiap orang berhak bebas dan berhak dari perlakuan yang bersifat diskriminatif atas dasar apa pun dan berhak mendapatkan perlindungan terhadap perlakuan yang bersifat diskriminatif itu."

Berdasarkan laporan Komnas Perempuan akhir 2014 ada 365 perda diskriminatif. Diskriminasi diantaranya

52 Musdah Mulia, Muslimah Reformis Perempuan Pembaru Keagamaan (Bandung: Mizan, 2005), 222-223

53 Zaitunah Subhan, Al-Quran dan Perempuna menuju Kesetaraan Gender dalam Penafsiran, (Jakarta: Kencana, 2015), 1 membatasi ruang dan waktu gerak, pemaksaan berbusana sesuai agamanya, serta minimnya advokasi terhadap perempuan korban kekerasan. Dari data itu, jika dirinci ada 90 pengaturan cara berpakaian, 124 kriminalisasi perempuan atas nama penertiban pornografi/pornoaksi/prostitusi, $\quad 32$ perda tentang pemisahan ruang publik antara laki-laki dan perempuan, dan 35 perda tentang jam malam perempuan. Perda diskriminatif berdasarkan provinsi adalah 90 di Jawa Barat, 46 perda di Sumatera Barat, 27 perda di Jawa Timur, 24 perda di Kalimantan Selatan dan 21 perda di Sulawesi Selatan. $^{54}$

Sebut saja, misalnya: Surat Imbauan Bupati Tanah Datar No.451.4/556/Kesra-200, Perihal Himbauan berbusana Muslim/Muslimah kepada Kepala Dinas Pendidikan dan Tenaga Kerja; Keputusan Bupati no.451/2712/ASSDA.I/200 tentang kewajiban memakai Jilbab di Cianjur; SK Bupati Dompu No KD. 19.05/ HM. 00/1330/2004, tentang pengembangan Perda No.1/2002 isinya Kewajiban memakai busana Muslim/ Jilbab. (islamedia.id). Dalam hal pengenaan jilbab maupun hijab, menurut Nasaruddin Umar penggunaannya sebelum Q.S. al-Ahza>b: 59, dan Q.S. al-Nu>r: 31 diturunkan. Kewajiban jilbab maupun hijab didasarkan pada etika, hukum, keamanan masyarakat setempat. Jilbab berfungsi menghindari dari ketidakamanan, yang tentunya sebagai kewajiban menjaga aurat. ${ }^{55}$

Yuniyanti Chuzaifah komisioner Komnas Perempuan mengatakan bahwa perda-perda diskirminatif berlawanan

\footnotetext{
${ }^{54}$ http://print.kompas.com/baca/2015/03/2 3/Perda-Diskriminatif-Bertentangan-denganKonstitusi (diakses 16 Juni 2016)

55 Nasaruddin Umar, Teologi Jender Antara Mitos dan Teks Kitab Suci (Jakarta: Pustaka Cicero, 2003), 172
} 
dengan Pancasila dan Undang-Undang Dasar 1945. Ini dampak dari mencampurkan cara bernegara dengan politisasi agama. Akibatnya, muncul kebijakan yang bersifat sekadar pembatasan, tetapi tidak mencakup halhal yang substantif. Padahal, penerapan kebijakan menggunakan pajak dari rakyat yang terkena dampak negatif perda tersebut. Diungkapkan Irawati Harsono Komisioner lainnya, bahwa secara substansi, dalam melindungi perempuan bisa melalui pendidikan, pemberdayaan, maupun menambah skill dalam bekerja.

Data tahun 2010 Komnas Perempuan, ada 19 kebijakan (provinsi), dan 134 regulasi (kabupaten/ kota) serta 1 regulasi desa dari 19992009. Ada 63 perda diskriminatif langsung kepada perempuan yang menyangkut pengurangan hak atas perlindungan dan kepastian hukum karena mengkriminalkan perempuan. Ditambah lagi sebanyak 37 regulasi yang terkait dengan prostitusi, penghapusan hak atas perlindungan dan kepastian hukum (1 kebijakan tentang larangan khalwat), dan pengabaian hak atas perlindungan (4 kebijakan tentang buruh migran). Komnas Perempuan menilai bahwa otonomi daerah dengan regulasinya harus mengandung nilainilai kemanusiaan, memberikan perlindungan dengan penegakkan hak asasi manusia serta perda yang tidak diskriminatif. $^{56}$

Dalam asumsi penulis, pasal-pasal stigmatisasi negatif terhadap perempuan dalam perda syari $>$ ah. Salah satu penyebab munculnya regulasi diskriminatif terhadap perempuan disebabkan hukum patriarki dan jauh

56 Komnas Perempuan, “Atas Nama Otonomi Daerah: Pelembagaan Diskriminasi dalam Tatanan Negara-Bangsa Indonesia, Laporan Pemantauan Kondisi Pemenuhan Hak-Hak Konstitusional Perempuan di 16 Kabupaten/Kota pada 7 Provinsi, " (Laporan Komnas Perempuan, 2010) dari konsep maqa>shid syari> 'ah yang selaras dengan nilai-nilai HAM. Karenanya, hukum jadi konservatif. Moh. Mahfud MD menilai, munculnya hukum konservatif, yaitu adanya konfigurasi politik yang jauh dari demokratis serta menjadikan hukum sebagai subordinat politik.

Karenanya, penulis melihat perda syari>'ah sebagai hukum konservatif. Ciri-cirinya sebagaimana diungkapkan Moh. Mahfud MD, diantaranya adalah proses pembuatan hukum yang sentralistik yang artinya tidak partisipatif; di dalamnya mengandung sifat positivist-instrumentalistik, hanya mengakomodasi keinginan dan instrumen pembenaran penguasa; ada keragaman penafsiran karena open responsive (tidak responsif); dan dalam penegakkannya sebagai program dalam waktu singkat, bukan mengutamakan hukum yang sudah berjalan. ${ }^{57}$

Husein

Muhammad menggarisbawahi atas semua jenis hukum yang dilahirkan harus berdasarkan asas kemaslahatan. Sama dengan Masdar Farid, ia mengambil pandangan Abdul Hamid Al-Ghazali merumuskan tujuan kontruksi hukum dengan al-kulliyat al-khams untuk menjaga: agama/keyakinan, jiwa dan tubuh, akal dan rasio, keturunan, serta kepemilikan harta. ${ }^{58}$

Di sisi lain yang sangat penting diperhatikan adalah, regulasi syariah harus berpedoman kepada regulasi tertinggi, baik secara nasional (konstitusi negara) maupun regulasi internasional. Pertama, UUD 1945 pasal 5 ayat (1), pasal 20, pasal 27 ayat (1), pasal 28, pasal 28A, pasal 28B, pasal $28 \mathrm{C}$, pasal $28 \mathrm{D}$, pasal $28 \mathrm{E}$, pasal

57 Moh. Mahfud MD, "Langkah Politik dan Bingkai Paradigmatik dalam Penegakkan Hukum Kita," (Kumpulan Makalah Politik Hukum Moh. Mahfud MD, Program Pasca Sarjana (S-2) Ilmu Hukum, Universitas Indonesia, 2004), 3

58 Husein Muhammad, Islam Agama Ramah Perempuan (Yogyakarta: LKiS, 2004), 93 
$28 \mathrm{~F}$, pasal $28 \mathrm{G}$, pasal $28 \mathrm{H}$, pasal 28I, pasal 28J, pasal 31, pasal 32, pasal 33, pasal 34 ayat (2) dan ayat (3); Kedua, UU No 7/1984 tentang Pengesahan Konvensi mengenai Penghapusan Segala Bentuk Diskriminasi terhadap Wanita (Convention on the Elimination of All Forms of Discrimination Against Women); ${ }^{59}$ Ketiga, UU No 39/1999 tentang Hak Asasi Manusia; ${ }^{60}$ Keempat, UU No 11/2005 tentang Pengesahan International Covenant on Economic, Social and Cultural Rights (Kovenan Internasional tentang Hak-Hak Ekonomi, Sosial dan Budaya); ${ }^{61}$ Kelima, UU No 12/2005 tentang Pengesahan International Covenant On Civil and Political Rights (Kovenan Internasional tentang Hak-Hak Sipil dan Politik). ${ }^{62}$

\section{KESIMPULAN}

Dalam sejarah hukum Indonesia. Hukum Islam sudah dimasukkan dalam hukum negara sejak penjajahan oleh Hindia Belanda. Melalui politik hukumnya, bisa dilacak dalam Undangundang Hindia Belanda Reglement op het beleid der Regeering van Nederlandsch Indie atau Regeerings Reglement (R.R.) Stbl. 18552:2. Kemudian diperkuat setelah VOC datang. VOC mengesahkan Resolutie der Indische Regeering di 25 Mei 1760 dan Regeeringsreglement tahun 1855 pasal 75 ayat 3 R.R. Hukum Islam itu terkait hukum perkawinan dan waris.

59 Lembaran Negara Republik Indonesia Tahun 1984 Nomor 29, Tambahan Lembaran Negara Republik Indonesia Nomor 3277

60 Lembaran Negara Republik Indonesia Tahun 1999 Nomor 165, Tambahan Lembaran Negara Republik Indonesia Nomor 3886

${ }^{61}$ Lembaran Negara Republik Indonesia Tahun 2005 Nomor 118, Tambahan Lembaran Negara Republik Indonesia Nomor 4557

${ }^{62}$ Lembaran Negara Republik Indonesia Tahun 2005 Nomor 119, Tambahan Lembaran Negara Republik Indonesia Nomor 4558. Perhatikan landasan hukum dalam RUU KKG (Kesetaraan Gender)
Kehadirannya perda-perda syari $>$ 'ah sejatinya seperti pengulangan sejarah. Beda waktu dan konteksnya. Sebagai hukum yang bersumber dari kompromi politik, penafsiran dari beragam kelompok masyarkat yang berbeda latar pendidikannya. Tidak menutup kemungkinan terjadi kekeliruan dan kekurangan dalam penerapannya. Sebagaimana diketahui, di Islam sangat beragam madzhab dan pemikirannya. Satu sama lain, tidak selalu sama.

Diwujudkan dalam peraturan daerah yang diuji publik secara lokal, belum tentu bisa beradaptasi dengan regulasi tertinggi. Kalangan feminis Islam sendiri banyak yang menolak karena banyak regulasi yang tidak rasional dan diskriminatif. Terutama perda-perda yang berhubungan dengan hak-hak perempuan. UU HAM BAB $\mathrm{XA}$ secara gamblang memberi jaminan bagi setiap warga untuk hidup dan bertahan (pasal 28A), berkeluarga dengan jaminan anak yang lahir terjamin tumbuh, tanpa kekerasan maupun diskriminasi (pasal 28B 1 dan 2, berkembang dan berpendidikan (pasal 28C 1), setiap warga wajib menghormati HAM individu yang lain dalam tertib kehidupan bermasyarakat, berbangsa dan bernegara (pasal 28J 1). Dan secara ekspilisit di pasal 2, disebutkan regulasi untuk menjamin hak dan kebebasan orang lain dan untuk memenuhi tuntutan yang adil sesuai dengan pertimbangan moral, nilai-nilai agama, keamanan dan ketertiban umum dalam suatu masyarakat demokratis.

Teori postmodernisme yang bervisikan egalitarianisme salah satunya. Telah memeberikan dorongan kepada pemikiran feminis Islam untuk terus menyuarakan kemerdekaan. Secara konsisten sesuai dengan karakter postmodernitas menghargai heterogenitas, dan keberaragaman serta menafsir ulang wacana yang telah mapan. Dan ada terjaminnya HAM 
secara global. Bidang-bidang ekonomi, politik, budaya maupun hukum bebas berekspresi.

Terbitnya perda-perda yang "diskriminatif" terhadap perempuan merupakan buah dari desentralisasi. Daerah memberikan kewenangan kepada pemerintah daerah mengatur daerahnya, kecuali 6 hal yaitu politik luar negeri, pertahanan, keamanan, yustisi, moneter dan fiskal nasional dan agama. Kalangan feminis Islam yang kontra, memandang perda syariah diskriminatif dan bertentangan dengan Pancasila dan UUD 1945. Perempuan sebagai sub-ordinat laki-laki dikekang kebebasannya. Hukum patriarkal yang dimiliki perda itu merampas hak-hak perempuan. Karenanya bertentangan dengan HAM.

Di tengah perdebatan pro dan kontra. Pemerintah menerbitkan dua regulasi, yaitu Peraturan Presiden tentang Pengarusutamaan Gender dan terbitnya Peraturan Menteri Kesehatan tentang Kesehatan Reproduksi. Dua regulasi itu sebagai implementasi dari Beijing atau Beijing Declaration and Platform for Action (BPFA) yang telah deklarasi 20 tahun lalu.

\section{DAFTAR PUSTAKA}

Kodir, Faqidudin Abdul, Shalawat Keadilan Relasi Laki-laki dan Perempuan dalam Teladan Nabi, (Cirebon: Fahmina Institute, 2003)

Al-Siba>'i, Musthafa, al-Mar'ah baina alFiqh wa al-Qa>nu>n (Damaskus, Halb: al-Maktabah al-'Arabiyat)

Azra, Azyumardi,"Syariat Islam dalam Bingkai Nation State," dalam Komaruddin Hidayat dan Ahmad Gaus (ed.), Islam, Negara dan Civil Soceity, Gerakan dan Pemikiran Kontemporer (Jakarta: Paramadina, 2005)
Badran, Margot, "Understanding Islam, Islamism and Feminism" dalam Women and Islam: Critical in Sociology, ed. Haidah Moghissi (New York: Routledge, 2005)

Branston, Gill and Roy Stafford, The Media Student's Book, Third Edition, (London and New York: Routledge, 2003),387-340.

Cox, Harvey, Religion and the Secular City: Toward a Postmodernism Theology (New York: Simon and Schuster, 1984)

Davies, Margaret, Asking the Law Question (The Law Book Company Ltd, 1994)

Farid, Masdar Mas'udi, Syarah Konstitusi UUD 1945 Dalam Perpekstif Islam (Jakarta: Alvabet, 2011)

Friedman, Harry, "Decentralized Development in Asia," dalam G. Shabbir Cheema dan Denndi A. Rondinelli (Editors), Decentralization and Development Policy Implementationa in Developing Countries (Beverly Hills/ London/ New Dehli, Sage Publication: 1983)

Huda, Ni'matul, Hukum Pemerintahan Daerah (Bandung: Nusa Media, 2012), cet-III

Ibn Ahmad, Muhammad ibn 'Abd al$\mathrm{Ha}>\mathrm{di}>\quad$ al-Dimashqi> (744), Thabaqa $>t$ 'Ulama $>$ al-Hadith (Beirut: Muassasah al-Risa>lah, 1996), C. II, tahqi $>$ q: Akram al$\mathrm{Bu}>$ shi dan Ibra>hi>m al-Zaybaq), Juz II

Irsyadunnas, Hermeneutika Feminisme dalam Pemikiran Tokoh Islam Kontemporer (Yogyakarta: Kaukaba, 2013) 
Jary, David and Julia Jary, Collins Dictionary of Sociology (Glasgow: Harper Collins Publisher, 1991)

Kamil, Syukron, Pemikiran Islam Tematik Agama dan Negara, Demokrasi, Civil Society, Syariah dan HAM, Fundamentalisme dan Anti Korupsi (Jakarta: Kencana Prenada Media Group, 2013)

------ (ed.), Syariah dan HAM Dampak Perda Syariah terhadap Kebebasan Sipil, Hak-hak Perempuan, dan NonMuslim (Jakarta: CSRC UIN Jakarta dan KAS Jakarta, 2007), xxii

Lash, Scott, Sosiologi Postmodernisme, (Yogyakarta: Pustaka Filasafat Kanisius, 2008)

Mahfud, Moh. MD, "Langkah Politik dan Bingkai Paradigmatik dalam Penegakkan Hukum Kita," (Kumpulan Makalah Politik Hukum Moh. Mahfud MD, Program Pasca Sarjana (S-2) Ilmu Hukum, Universitas Indonesia, 2004)

Mernisi, Fatimah, Beyond the Veil MaleFemale Dinamics in Modern Muslim Society (Indiana: Indiana University Press, 1987)

Muhammad, Husein, Islam Agama Ramah Perempuan (Yogyakarta: LKiS, 2004)

Musdah, Siti Mulia (ed.) Keadilan dan Kesetaraan Gender Perspektif Islam (Jakarta: Lembaga Kajian Agama dan Jender, 2003)

--------, Muslimah Reformis Perempuan Pembaru Keagamaan (Bandung: Mizan, 2005)

Munawar, Budhi Rahman, "Islam dan Feminisme: dari Sentralisme kepada
Kesetaraan," dalam Membincang Feminisme Diskursus Gender Perspektif Islam, ed. Mansur Faqih (Surabaya: Risalah Gusti, 1995)

Ray, David Grifft, Tuhan dan Agama dalam Dunia Postmodernisme (Yogyakarta: Pustaka Filsafat Kanisius, 2005), 17

Ruhaini, Siti Dzuhayatin, Rezim Gender Muhammadiyah Kontestasi Gender, Identitas dan Eksistensi (Yogyakarta: Suka Press-Pustaka Pelajar, 2015)

S. Lev, Daniel, Hukum dan Politik di Indonesia (Jakarta: LP3ES, 2013), cet. ke-3

Sadli, Saparinah, "Hak Asasi Perempuan Juga Hak Asasi Manusi," dalam Berbeda tetapi Setara, (Jakarta: Kompas Media Nusantara, 2010)

Salim, Arskal and Azyumardi Azra (eds), Sharia and Politics in Modern Indonesia, diedit oleh Arskal Salim dan Azyumardi Azra, Singapore: ISEAS, 2003

Savitri, Niken, HAM Perempuan Kritik Teori Hukum Feminis Terhadap KUHP (Bandung: Refika Aditama, 2008)

Subhan, Zaitunah, Al-Qur'an dan Perempuan, (Jakarta: Kencana, 2015), 1

--------, Al-Qur'an dan Perempuan Menuju Kesetaraan Gender dalam Penafsiran (Jakarta: Prenada Media Group, 2015), 3

Suny, Ismail, "Hukum Islam dalam Hukum Nasional" dalam Jejak-jejak Hukum Islam dalam Sistem Ketatanegaraan Indonesia (Jakarta: Konpress, 2005) 
Umar, Nasaruddin, Perspektif Jender Dalam Al-Qur'an (Disertasi: IAIN Syarif Hidayatullah Jakarta, 1999)

Umar, Nasaruddin, Teologi Jender Antara Mitos dan Teks Kitab Suci (Jakarta: Pustaka Cicero, 2003)

Appignanesi, Richard dan Chris Garratt, Mengenal Postmodernisme for Beginners (Bandung: Mizan, 1998)

Wanita PUI, Pedoman Dasar dan Pedoman Rumah Tangga Wanita Persatuan Ummat Islam (Wanita PUI), (Jakarta: Wanita PUI, 2011)

Yusanto, Ismail, "Selamatkan Indonesia dengan Syariat" dalam Burhanudin (ed.)Syariat Islam Pandangan Muslim Liberal (Jakarta: JIL dan TAF, 2003)

\section{Jurnal:}

Chandradewi, Renny, "Modernisme dan Postmodernisme Review Tulisan David Harvey" dalam Journal Issue: Vol. 1/No. 04/27 March 2014

Razi, Shafwan, "Agama dan Postmodernisme: Menelusuri Metodologi dan Pendekatan StudiStudi Agama" dalam Ilmu Ushuluddin, Volume 1, Nomor 3, Januari 2012.

Nashir, Haedar, Gerakan Islam Syariah (Jakarta: Maarif Institute, 2006), 74 vol. 1 No. 02 Novemer 2006

\section{Website/Media Online:}

www.pusakaindonesia.org

Sejarah Pergerakan Perempuan Indonesia. http://www.scrib.com. (diakses 17 Juni 2016) http://print.kompas.com/baca/2015/03/23/ Perda-Diskriminatif-Bertentangandengan-Konstitusi (diakses 16 Juni 2016)

\section{Dokumen:}

Lembaran Negara Republik Indonesia Tahun 1984 Nomor 29, Tambahan Lembaran Negara Republik Indonesia Nomor 3277

Lembaran Negara Republik Indonesia Tahun 1999 Nomor 165, Tambahan Lembaran Negara Republik Indonesia Nomor 3886

Lembaran Negara Republik Indonesia Tahun 2005 Nomor 118, Tambahan Lembaran Negara Republik Indonesia Nomor 4557

Lembaran Negara Republik Indonesia Tahun 2005 Nomor 119, Tambahan Lembaran Negara Republik Indonesia Nomor 4558.

RUU KKG (Kesetaraan Gender) yang belum disahkan. 